\title{
Sudanese EFL Students' Preferred Learning Styles and Evaluation Techniques
}

\author{
Awwad Othman Abdelaziz Ahmed \\ Department of Foreign Languages, Taif University, PO box 888, Taif 21974, KSA
}

\begin{abstract}
The effectiveness of learning in any language is usually determined by the type of learning styles adopted by the language learner himself. This study traces the heterogeneous learning style used by EFL undergraduate students in the department of English language, Faculty of Education, University of Khartoum in Sudan. The study took place during the academic year 2016 / 2017. Undergraduate students have miscellaneous strategies they recommend to use promptly inside the classroom. To function productively in classrooms, teachers should think about their students' favored learning styles because at this university level students have different backgrounds, strengths, weaknesses, concerns, desires, and even they have different levels of motivation and styles to studying. Thus, teachers should be more acquainted with the divergent methods to their students' better learning. A questionnaire was given out to (205) male and female students which covered twenty-five indispensable items in learning styles. Students responses were analyzed statistically to measure the efficiency of these learning styles used by the students in the department of English language and work out whether the distribution of learning styles was distinct over the four years of the program. Results revealed that there existed notable mismatch and correspondences in learned style choices. This indicated that students have affirmative perspective towards learning styles. Thus, teachers should regard their students' preferred learning styles and try to use different teaching styles inside the classroom to avoid monotonous classes that are not harmonized with their students' learning styles. Suggestions are stated for required future research in finding out how language learning styles can reinforce students in becoming more competent foreign language learners.
\end{abstract}

Keywords: Learning styles, Evaluation techniques, Sudanese EFL students

DOI: $10.7176 / \mathrm{JEP} / 10-3-15$

\section{Introduction}

Much has been demonstrated about learning styles and evaluation techniques and their valuable roles in the process of language learning over the last few decades. It is obvious that learning style research has been in progress and it is reported that in accordance with language teaching and learning during the past twenty years and so, a progressive notable modification occurred and caused a slighter burden on teachers and language instruction and better positiveness on students (Nunan, 1988). Learning styles are practically implemented to assist students and teachers who appreciate how to enhance the style they learn and teach accordingly. Learning styles or preferences are resourceful ways in which learners recognize, convert, maintain and remember what they are trying to learn. This paper describes leaning styles as a progressive learning context to set up learner knowledge of language learning procedures. Learners' preferable techniques can be influenced by how to respond to one's intimate speech duration backgrounds, their ways to be taught and their former knowledge practices. Students normally have their own styles when carrying out particular tasks and this usually comes by practicing over times.

Considering learning styles attentively, a teacher will regard multiple techniques and strategies of teaching, and that is a value itself. A professional teacher needs to adjust his techniques and have a variety of teaching methods and learning situations which can be designed from time to time. The idea is to promote high quality of learning for large numbers of students. From the researchers' point of view, some teachers form the inferences that they must match their teaching to the students' certain method, and some students who have been denominated as having a special style feel that they can only learn from a particular style of teaching. Thus, knowing about learning styles is useful to teachers who have not figured out early about distinction among their students. Pintrich (1990) emphasizes that teachers have great roles to do. One of them is to find out vivid styles that can make the students skillful and competent in handling different aspects of the language. This means that a distinguished teacher who stimulates his students to numerous teaching styles. In general, the studies on language learning styles have been of great importance. Although this area might hold much hope, it is still in its flourishing era.

This study tries to demonstrate the learning styles that assist students determine the suitable learning strategies and the types of evaluation techniques which their teachers use in their classes with regard to their own learning styles. In Sudanese context, there is little evidence that teachers vary their teaching style to fit their students' learning styles.

By exploring Sudanese EFL learners' preferred learning styles, this study aims at answering these questions and hypotheses: 
Q 1. What are the styles and learning strategies preferred by Sudanese EFL students?

Ho 1. English major students use limited learning styles.

Q 2. What types of evaluation techniques do teachers use to measure their students' performance?

Ho.2 Teachers use different types of evaluation techniques to measure their students' performance.

Q 3. To what extent do students have positive attitude towards learning styles?

Ho.3 Learners have positive attitude regarding the use of styles.

This study adopts the descriptive and analytical methods. Data will be collected by means of students' questionnaire and responses will be elicited from both girls and boys. Moreover, data will be analyzed and presented in tables.

\section{Literature Review}

The two terms "learning strategy and "learning styles" have different meanings and uses in an EFL context. Reid (1995) defined "Learning strategy" as apparent skills that learners use, often purposefully, to strengthen their learning; they can be presented as guided techniques which enable students to promote or enlarge the current learning styles which they use, whereas "learning styles" defined as inside based features, commonly not apprehended or used advisedly. Oxford (1995) defines learning style as methods or approaches used to learn languages. In other words, Oxford goes to say that any particular action used by the student to simplify learning styles and make it active, pleasing, challenging, successful, and transmissible to authentic contexts can be called a learning style. Moreover, Wenden (1987:6) emphasizes that learning styles are methods, procedures, or intended situations that students use in order to stimulate their knowledge.

As stated earlier that the purpose of learning styles is to enhance knowledge in an adequate way for learners in such setting whenever means are insufficient (e.g. duration inadequacy, teachers' insufficiency, or high-priced computer devices). Before using learning styles, students recommend some orientation to the conception of language learning styles. It might occur during class setting or presented issues. Moreover, it can be effective for monitoring classroom seminars which allow an instructor to present the concept by manipulating styles that suit a particular activity. That is essential due to the fact that a number of failed students is identified and once they utilize styles, they are considered productive students (Van \& Abraham, 1990).

Diverse investigators namely; (Lovelace, (2005); Ogden, (2003); Flores, (2012) review that learners will acquire adequately when they study in ways that match their learning. Kang (1999) points out that students acquire adequately when learning is related to their actual abilities. When teaching patterns are fitted for relevant techniques, thereafter their positive stimulus, performing, and implementations will be strengthened and improved accordingly. Flores (2012) also claims that there are three principal styles that can be used in classroom practices. These are the acoustic learner style, the visible learner style and the proprioceptive learner style. Several articles on developing learning abilities focus on these three types of styles. As for the acoustic learners, those are the learners who listen and learn. They grasp information by exclusively listening. They can stay in considerable classes conveniently and get beneficial, plausible and significant knowledge. Ellis (1989) points out that proprioceptive learner is a person who recalls things perfectly when described in words or written form, $\mathrm{s} /$ he is also the one who learns best from books and class presentation. Ellis (1989) goes to emphasize that visible learners are learners who learn by vision. They are able to view the remedy to a difficulty. Once they internalize it in their minds, then they will be able to form and spell it. They may not able to trace oral direction well and function effectively when there is a list of items to do rather than being informed what to do. Furthermore, Ellis (1989) presents that the visual remembrance reports what comes via the eye. This means, it is the channel through which one memorizes what s/he looks up. This reflects that people over the world are wellaware of the latest teaching and learning technologies The third type refers to the active or dynamic learners who process information effortlessly and they follow practical steps in order to achieve learning. They misinterpret direction when delivered orally or visibly. Flores (2012) describes this type of learner as a learner who acquires his/her education through efficient instructions and methods. According to Dunn (1984), students have various "learning styles" to learn such as visualizing, hearing, expressing, representing and justifying reasonably and logically. Teachers also have various methods "teaching styles," some teach classes, others present, explain or argue; some focus on procedures and others on models; some focus on remembering and others on grasping. Numerous researchers declare that students with learning preferences, that suit them, get good marks. Dunn (1984) also demonstrates that several students can obtain easy information through false choices of styles, yet they can acquire effectively and quickly based on their favored styles. This means that if there is a mismatch between teaching styles and students' preferred learning style, it will create a huge gap in the learning process.

Academic research usually evaluates the effectiveness of teaching and learning styles. Land and Huxland (2000) suggest that instructors possibly try to find out in advance about their students' favored learning styles, then they can make their own adjustment and modification in order to make their classes more enjoyable and entertaining. At the present time, more educationalists recommend authentic teaching style to promote students' positive stimulus towards learning which leads to constructive results in teaching English as foreign language, 
particularly in the Sudanese context.

Brown (2003) indicates that it is necessary to direct learning techniques and strategies towards learners' exposure to various tasks and assist them develop skills essential for carrying out multiple learning needs. Rubin and Hebert (2003) confirm the formulation of dynamic tasks which stimulate mixed styles and involve the learners, fulfill students' needs, and preserving facts. Ogden (2003) adjusts the traditional class to involve the students in diverse strategies and concludes that learners study by their own determination when given chance for improving relevant potency in different domains. Brown (2003) also maintains that all learners are directed to a favored style of learning, and that coped with selecting best learning styles that can achieve and satisfy their needs namely; for those who study at the university level. Ellis (1989) states the fact for all teachers by clarifying that the approach through which one has learned is the approach through which one will use to teach. Both teachers and students should be furnished with various teaching and learning styles needed for achieving specific or general objectives. As Chamot (2008) mentions, all present educational patterns involve the progression of students' awareness which promote style preferences and aim to create active and proficient learners. The fundamental assumption of the learning styles is that students should be provided with the chance to perceive what they learn in the class more meaningfully and successfully. Learning styles help learners become more knowledgeable of what types of techniques are accessible to them, grasp how to set up and use styles consistently and adequately, how to select their learning style preferences and how to hand over these favored techniques in distinct language learning frameworks (Cohen, 2007). When teachers introduce a strategy or a style of learning, they usually involve some type of demonstration of a style to students, possibly introduced by warming up or debate, then practicing the method; after all an assessment of the adequacy of the method. Grenfell and Harris (1999), for instance, enumerate six principal stages:

- first to enhance students' knowledge

-second to assist them avail of the styles used

- third to present the styles in their new form

- fourth to practice the strategies

- fifth to orientate them in choosing the styles that address their own needs

- sixth to assess their improvement and the style in use.

Evaluation techniques such as paragraph/ essay questions, multiple choice, fill-ins, transformation items, matching items, completion items, sentence-combining, cloze tests, reading comprehension, cursory items, etc. share one feature, namely; they encompass devices which reinforce learning and motivate students. Evaluation is a major mean of the students' performance assessment in language teaching. Dhaouadi (2006) states that evaluation strengthens learning in diversity of methods not only by reporting instructors about the learning techniques and barriers face their learners but also by forming the educational objectives. Shohamy (2001: 4) suggests "some alternative evaluation parameters since they consider learners' various learning styles and skills ... assuring equality and integrity" (4). Coombe and Hubley (2004), Tannennbaum (1996), Black and William (1998) and McGlinchey (2004) also advocate students' active role in assessment process. Several research studies have been conducted to investigate students' preferences about evaluation including those of (Wilson-Hull, 2008; Kikuchi, 2005).

In this study, the learning styles used by the students of English department will be identified and investigated. It is expected that some of these styles may not suit every student. Rather some students have their own preferable ones.

\section{Methodology}

3.1 Participants

(115) male and (130) female students who are majoring in English, Faculty of Education at University of Khartoum in Sudan were nominated as measurable population for this study. They constitute various learning levels (Year 1- 4). Because of their B.A. study plan, there are multiple courses which are indispensable such as basic skills courses in the first two years of study, whereas in the third and fourth years of their study, there are the literature, translation and linguistics courses. This study took place during the academic year 2016/2017.

Table 1. Questionnaire Rate of Return

\begin{tabular}{|c|c|c|c|}
\hline No. & Sample & "Questionnaire distributed & Questionnaire collected \\
\hline 1 & Male & 115 & 95 \\
\hline 2 & female & 130 & 110 \\
\hline
\end{tabular}

95 males $(\mathrm{n} 1=95)$ and 110 females $(\mathrm{n} 2=110)$ of the samples gave back the questionnaire after filling in the needed details. 
Table 2. The Distribution of the Study Sample According to the Years of Study $(\mathrm{N}=205)$

\begin{tabular}{|c||c||c||c||c|}
\hline Year of Study & Male & Female & No. of Students & Percentage \\
\hline \hline First & 26 & 28 & 54 & 26.3 \\
\hline Second & 21 & 25 & 46 & 22.4 \\
\hline Third & 25 & 27 & 52 & 25.4 \\
\hline Fourth & 23 & 30 & 53 & 25.9 \\
\hline \hline Total & 95 & 110 & 205 & 100 \\
\hline
\end{tabular}

\subsection{Materials}

The most common and practical method for tracing students' learning styles is through questionnaires. The constraints are that students may not recall the techniques they have used earlier, or may not grasp the strategy identifications in the questionnaire items. For these reasons, a 25-item Likert-scale questionnaire was developed and grounded on Buch et. al. (1992) that basically included (100) items. Several items were omitted and some improved to satisfy two objectives; to meet the needs of these English-major Sudanese students and to reduce its items for the purpose of the sample' suitability.

\subsection{Procedure}

The questionnaire was meant to identify different features of the students' preferred learning styles and evaluation techniques. All questionnaire statements were to trace students' preferred learning styles except six items $(14,16,22,23,24$ and 25) that were incorporated to elicit their reaction with respect to their preferred evaluation techniques. Descriptive statistics namely; the mean (M), standard deviation (SD) and P-value were calculated to test the perception of both groups.

\section{Discussion and Results}

This section displays the analysis and discussion of the data that has been collected by means of a questionnaire to (95) male students and (110) female students. This section also targets to take an action towards the questions and assumptions of the study against the results obtained.

In the following tabulation, one sample $t$ test is used to check if the opinions of the respondents are positive ( $p$-value is higher than 0.05 ) or the views of the participants are negative ( $p$-value is lower than 0.05).

Table 3. Statistical Analysis of the Students' Questionnaire

\begin{tabular}{|c|c|c|c|c|c|c|c|c|c|}
\hline \multicolumn{2}{|c|}{ Statement } & Gender & $\mathbf{N}$ & M & SD & $T$ & df & \multicolumn{2}{|c|}{ p value } \\
\hline \multirow[t]{2}{*}{1} & \multirow{2}{*}{$\begin{array}{l}\text { I learn better once I } \\
\text { follow the textbook } \\
\text { intimately. }\end{array}$} & Male & 95 & 2.8221 & 1.1155 & -2.063 & 238 & .042 & \multirow{2}{*}{$\begin{array}{l}\mathrm{p}< \\
0.05\end{array}$} \\
\hline & & Female & 110 & 3.5899 & 3.7177 & -2.261 & 160.866 & .027 & \\
\hline \multirow[t]{2}{*}{2} & \multirow{2}{*}{$\begin{array}{l}\text { If I feel that I don't know } \\
\text { to respond to a question } \\
\text { that I have been asked } \\
\text { then I attempt to find a } \\
\text { reply. }\end{array}$} & Male & 95 & 3.5462 & 1.0258 & .3198 & 248 & .761 & \multirow{2}{*}{$\begin{array}{l}p_{0}> \\
0.05\end{array}$} \\
\hline & & Female & 110 & 3.5100 & 1.2257 & .326 & 247.228 & .756 & \\
\hline \multirow[t]{2}{*}{3} & \multirow{2}{*}{$\begin{array}{l}\text { I learn best when the } \\
\text { teacher makes learning } \\
\text { enjoyable. }\end{array}$} & Male & 95 & 2.9255 & 1.3502 & .953 & 239 & .342 & \multirow{2}{*}{$\begin{array}{l}p_{1}> \\
0.05\end{array}$} \\
\hline & & Female & 110 & 3.0906 & 1.3235 &.-950 & 223.369 & .343 & \\
\hline \multirow[t]{2}{*}{4} & \multirow{2}{*}{$\begin{array}{l}\text { I like to practice using } \\
\text { grammar forms. }\end{array}$} & Male & 95 & 2.9907 & .9310 & .051 & 238 & .021 & \multirow{2}{*}{$\begin{array}{l}\mathrm{p}< \\
0.05\end{array}$} \\
\hline & & Female & 110 & 2.9873 & 1.1185 & .054 & 212.064 & .023 & \\
\hline \multirow[t]{2}{*}{5} & \multirow{2}{*}{$\begin{array}{l}\text { I prefer getting other } \\
\text { meanings from the } \\
\text { contexts in which words } \\
\text { existed. }\end{array}$} & Male & 95 & 3.5867 & 1.2449 & .303 & 252 & .786 & \multirow{2}{*}{$\begin{array}{l}\mathrm{p}> \\
0.05\end{array}$} \\
\hline & & Female & 110 & 3.5397 & 1.1998 & .301 & 221.821 & .775 & \\
\hline \multirow[t]{2}{*}{6} & \multirow{2}{*}{$\begin{array}{l}\text { I understand very best } \\
\text { through regular watching } \\
\text { of films. }\end{array}$} & Male & 95 & 3.5285 & 1.2131 &.-110 & 246 & .924 & \multirow{2}{*}{$\begin{array}{l}p_{0}> \\
0.05\end{array}$} \\
\hline & & Female & 110 & 3.5458 & 1.1216 &.-109 & 216.788 & .924 & \\
\hline \multirow[t]{2}{*}{7} & \multirow{2}{*}{$\begin{array}{l}\text { Multiple activities } \\
\text { enable me to learn well. }\end{array}$} & Male & 95 & 3.5577 & 1.3538 & -2.517 & 239 & .014 & \multirow{2}{*}{$\begin{array}{l}\mathrm{p}< \\
0.05\end{array}$} \\
\hline & & Female & 110 & 3.9480 & 1.0581 & -2.450 & 195.018 & .016 & \\
\hline \multirow[t]{2}{*}{8} & \multirow{2}{*}{$\begin{array}{l}\text { I get improved when I } \\
\text { learn alone. }\end{array}$} & Male & 95 & 3.2173 & 1.1714 & -2.166 & 239 & .041 & \multirow{2}{*}{$\begin{array}{l}\mathrm{p}< \\
0.05\end{array}$} \\
\hline & & Female & 110 & 3.5449 & 1.1611 & -2.164 & 224.558 & .042 & \\
\hline 9 & I learn better when the & Male & 95 & 3.3587 & 1.0886 & .875 & 239 & .384 & $\mathrm{p}>$ \\
\hline
\end{tabular}




\begin{tabular}{|c|c|c|c|c|c|c|c|c|c|}
\hline \multicolumn{2}{|c|}{ Statement } & \multirow{2}{*}{$\begin{array}{l}\text { Gender } \\
\text { Female }\end{array}$} & \multirow{2}{*}{$\begin{array}{l}\mathbf{N} \\
110\end{array}$} & \multirow{2}{*}{$\begin{array}{l}\mathbf{M} \\
3.2856\end{array}$} & \multirow{2}{*}{$\begin{array}{l}\text { SD } \\
1.1357\end{array}$} & \multirow{2}{*}{$\begin{array}{l}\mathbf{T} \\
-879\end{array}$} & \multirow{2}{*}{$\begin{array}{l}\text { df } \\
229.396\end{array}$} & \multicolumn{2}{|c|}{ p value } \\
\hline & $\begin{array}{l}\text { teacher is observant and } \\
\text { administers the students } \\
\text { well. }\end{array}$ & & & & & & & .382 & 0.05 \\
\hline \multirow[t]{2}{*}{10} & \multirow{2}{*}{$\begin{array}{l}\text { Interaction with other } \\
\text { learners help me learn } \\
\text { well. }\end{array}$} & Male & 95 & 3.1606 & 1.2125 & -1.780 & 240 & .088 & \multirow{2}{*}{$\begin{array}{l}p_{1}> \\
0.05\end{array}$} \\
\hline & & Female & 110 & 3.4329 & 1.1536 & -1.770 & 220.115 & .083 & \\
\hline \multirow[t]{2}{*}{11} & \multirow{2}{*}{$\begin{array}{l}\text { The use of pictures } \\
\text { promotes me to learn. }\end{array}$} & Male & 95 & 3.5851 & 1.3999 & -1.009 & 241 & .315 & \multirow{2}{*}{$\begin{array}{l}\mathrm{p}_{0}> \\
0.05\end{array}$} \\
\hline & & Female & 110 & 3.7671 & 1.3758 & -1.008 & 223.513 & .316 & \\
\hline \multirow[t]{2}{*}{12} & \multirow{2}{*}{$\begin{array}{l}\text { I like learning in groups } \\
\text { not more than two. }\end{array}$} & Male & 95 & 2.8399 & 1.0616 &.-567 & 241 & .575 & \multirow{2}{*}{$\begin{array}{l}p_{0}> \\
0.05\end{array}$} \\
\hline & & Female & 110 & 2.9181 & 1.0698 &.-568 & 226.199 & .575 & \\
\hline \multirow[t]{2}{*}{13} & \multirow[t]{2}{*}{ I like group work. } & Male & 95 & 3.4861 & 1.1615 &.-659 & 241 & .043 & \multirow{2}{*}{$\begin{array}{l}\mathrm{p}< \\
0.05\end{array}$} \\
\hline & & Female & 110 & 3.5899 & 1.2521 &.-668 & 230.318 & .042 & \\
\hline \multirow[t]{2}{*}{14} & \multirow{2}{*}{$\begin{array}{l}\text { I study best when the } \\
\text { teacher gives frequent } \\
\text { duties. }\end{array}$} & Male & 95 & 3.2268 & 1.2370 & -1.010 & 239 & .317 & \multirow{2}{*}{$\begin{array}{l}\mathrm{p}> \\
0.05\end{array}$} \\
\hline & & Female & 110 & 3.3885 & 1.2321 & -1.009 & 225.063 & .317 & \\
\hline \multirow[t]{2}{*}{15} & \multirow{2}{*}{$\begin{array}{l}\text { I learn best when the } \\
\text { teacher explains in my } \\
\text { native language. }\end{array}$} & Male & 95 & 3.4250 & 1.1790 & -2.340 & 239 & .022 & \multirow{2}{*}{$\begin{array}{l}\mathrm{p}< \\
0.05\end{array}$} \\
\hline & & Female & 110 & 3.7615 & 1.0493 & -2.309 & 212.067 & .024 & \\
\hline \multirow[t]{2}{*}{16} & & Male & 95 & 3.4436 & 1.1961 & -2.144 & 241 & .034 & $\mathrm{p}<$ \\
\hline & $\begin{array}{l}\text { corrected by the teacher } \\
\text { without delay. }\end{array}$ & Female & 110 & 3.7615 & 1.0984 & -2.122 & 215.934 & .036 & 0.05 \\
\hline 17 & I study better when the & Male & 95 & 3.4909 & 1.2054 &.-877 & 241 & .384 & $\mathrm{p}>$ \\
\hline & $\begin{array}{l}\text { teacher moving round } \\
\text { the class and helps us. }\end{array}$ & Female & 110 & 3.6198 & 1.0749 &.-866 & 212.319 & .391 & 0.05 \\
\hline 18 & I feel more focused & Male & 95 & 3.9814 & 1.1213 & -1.306 & 242 & .195 & $\mathrm{p}>$ \\
\hline & $\begin{array}{l}\text { when the teachers } \\
\text { provide us with the } \\
\text { correct answer. }\end{array}$ & Female & 110 & 4.1646 & 1.0498 & -1.296 & 218.206 & .199 & 0.05 \\
\hline 19 & It is preferable to sort & Male & 95 & 3.9908 & 1.1675 &.-880 & 241 & .003 & $\mathrm{p}<$ \\
\hline & out the errors by myself. & Female & 110 & 4.1196 & 1.0976 &.-875 & 218.742 & .004 & 0.05 \\
\hline 20 & I welcome comments & Male & 95 & 3.3210 & 1.2391 & -2.368 & 241 & .020 & $\mathrm{p}<$ \\
\hline & $\begin{array}{l}\text { from each others more } \\
\text { than from our instructor. }\end{array}$ & Female & 110 & 3.7019 & 1.2391 & -2.367 & 225.453 & .020 & 0.05 \\
\hline 21 & It is preferably to take a & Male & 95 & 3.3681 & 1.1658 & -1.181 & 242 & .243 & $\mathrm{p}>$ \\
\hline & $\begin{array}{l}\text { sequence of small sub- } \\
\text { tests instead of one huge } \\
\text { exam. }\end{array}$ & Female & 110 & 3.5451 & 1.1481 & -1.178 & 223.881 & .242 & 0.05 \\
\hline 22 & I learn best when the & Male & 95 & 3.3209 & 1.2542 &.-136 & 241 & .896 & \\
\hline & $\begin{array}{l}\text { teacher gives frequent } \\
\text { examinations. }\end{array}$ & Female & 110 & 3.3438 & 1.3499 &.-137 & 231.880 & .895 & 0.05 \\
\hline 23 & I prefer multiple choice & Male & 95 & 3.1230 & 1.3075 & -1.074 & 241 & .286 & $\mathrm{p}>$ \\
\hline & $\begin{array}{l}\text { examinations to essay- } \\
\text { type questions. }\end{array}$ & Female & 110 & 3.2989 & 1.2270 & -1.070 & 218.510 & .291 & 0.05 \\
\hline 24 & I would like to know & Male & 95 & 2.2174 & 1.2652 &.-855 & 241 & .396 & $\mathrm{p}>$ \\
\hline & $\begin{array}{l}\text { more about test taking } \\
\text { techniques. }\end{array}$ & Female & 110 & 2.3661 & 1.4014 &.-866 & 233.832 & .390 & 0.05 \\
\hline 25 & I feel comfortable when & Male & 95 & 3.2456 & 1.3227 & .301 & 242 & .765 & $\mathrm{p}>$ \\
\hline & my peers correct me. & Female & 110 & 3.1944 & 1.3067 & .301 & 224.200 & .767 & 0.05 \\
\hline
\end{tabular}

It seems that the majority of the sample members consider some statements more than the rest of the participants. P-values for the first and the second statements are $(p<0.05)$ which suggest that these members are analogical in terms of learning grammar rules in addition to follow the textbook very closely. Overviewing the results, they are valuable insights to psychological cornerstones for the participants as their liking for Arabic use is concerned. The results of statement (15) indicate that great numbers of the students do not prefer their instructors to use their own native language in order to explain various points in the classroom. This trend implies that it is unnecessary for instructors to use Arabic explanations in the classroom; a very common practice in the Sudanese academic institutions. The participants' responses regarding the classroom atmosphere suggest that they want to have lively and relaxed atmosphere in the classes and they do not like strictly disciplined 
classrooms. This trend has also highlighted another positive indicator towards efficient language instruction because much investigations emphasize the importance of the educational context in facilitating the learning process. Results of statements (19), (21) and (25) reflected highly valuable results that Sudanese EFL students, explained by the participants, never prefer to show their faults to their peers. Statements (6) and (11) have elicited students' responses regarding the use of films and pictures in the classrooms. The results of these two statements indicate that the samples are visual learners and the use of visual teaching aids enhances their learning. Statements (12) and (13) sought their preferences with regard to group and pair work and moderately got high rates. Although the results imply few preferences for these two beneficial language teaching techniques, English language instructors should make use of these styles to raise students' talk duration.

Statements (17, 18 and 19 respectively) indicate that learners want a good practitioner to provide them with correct knowledge without giving them time to figure out their errors by themselves. A low value was assigned to the item that sought the samples' responses to the question of correcting their mistakes. Statements (1) and (8) generated the participants' responses whether they tried to guess the answers by working alone and the (p-values) for both the statements have been $(p<0.05)$, this indicates that they do not like to work on their own to get the proper response and require their instructors to help them. The only statement that indicates samples' preferences to work of their own was the question that generated learners' answers to learn the meaning of unknown words through the context clue. It might be resulted from using the correct-clue method as a fundamental ELT technique to guess the meaning of the words they find in when they read.

The remaining five statements $(14,16,22,23$ and 24) secured samples' responses regarding their preferred test taking strategies and evaluation techniques. A significantly higher rate was ascribed to the statement (24) which investigated test taking techniques. A reasonable value suggests that English teachers need to use techniques that would help the students answer their examination in an efficient way. The sample responded negatively to statement (21) that transpired whether they prefer to take frequent examinations. A high value was calculated for the statement (23) that elicited samples' reaction towards their preferences for multiple-choice examination to essay-type questions. The data generated from all the above mentioned five questionnaire-items implies that Sudanese students do not like taking series of assignments and small quizzes during the course of their studies and they prefer one large multiple-choice examination at the end of the course.

The statistical representation for the information elicited from the girls' responses indicate they had positive responses towards statements (2) and (4) which identified them as deductive learners. Responding to the statement (15) which elicited whether they learn best when the teacher explains in their native language and the (p-value) revealed that they do not like their teachers' practice of using Arabic in English classrooms. Statements (3) and (9) suggested that the participants prefer their teachers make learning more entertaining. It is evident that friendly teachers are preferred as compared to the teachers who want to control their classes strictly. Statements (19) and (21) required the samples to describe their responses regarding correction from their teachers. A reasonable ( $\mathrm{p}$-value) was nominated to the statement that was related to the correction of their mistakes by their instructors but negative ( $\mathrm{p}$-value) was nominated for the statement that sought their responses involving correction of their mistakes by their peers. It seems some of the respondents don not want their peers to come to know their mistakes, but they like that mistakes should be corrected by their teachers. This trend is reinforced by the analysis of statement (20) that was about correcting their mistakes by themselves and the samples showed their disliking for this item by assigning negative ( $p$-value). The analysis of the statements that investigated their reaction towards the use of visual aids like videos, movies and pictures signify that they like their teachers use these aids more than their counterparts. Statement (12) checked whether the participants like learning in groups, and the responses indicate that they prefer this valuable teaching technique. Another related statement was the one about the use of group work, and the samples seemed to have apprehension about it. Girls' attitude seems different from boys in this regard because the boys assigned nearly the same level of preferences for group and pair work.

Statements (17), (18), and (19) provide useful views of the participants which exhibited strong preferences for these items. Statement (8) was meant to identify samples' reaction towards working alone and the second one was to elicit their responses regarding guessing the answers for unfamiliar questions. A considerable number of girls indicate that they do not like working alone in the classroom. This positive language learning attitude should be exploited by the instructor to practice group/ pair to provide maximum opportunities of mutual communication. The analysis of statement (7) shows that the members of the samples do not like to indulge themselves in various activities. Statement (5) elicits their responses about guessing the meaning of unfamiliar words through context clue method and this technique can be taught as a vocabulary learning technique. Statements (14), (16), (22), (23) and (24) elicit sample's responses regarding their preferred evaluation technique, and the analysis exhibits that the data generated by the girls' responses do not show significant differences. The sample showed their unwillingness to take frequent assignments. A reasonably ( $p$-value) has been reported for the question that seeks their teachers' advice about test taking strategies which would help them achieve higher grades in their examinations. Statement (21) suggests that the sample does not want their teachers to give them 
frequent tests and classroom quizzes, but they want to have a large test at the end of their course. The girls also exhibit their strong liking for multiple-choice examination by assigning considerable mean of (3.30) to statement (23) that is about the preference of multiple-choice examination to essay-type questions.

Moreover, table (3) shows whether the differences in the boys' or girls' perceptions regarding their preferred learning styles and evaluation techniques are significant or not. The (p-value) for the responses of both samples have been considered and Independent-samples T Test has been applied to identify this variation. The analysis of the questionnaire items reports that both sample groups, girls and boys, do not carry significant differences as far as majority of the questionnaire items are concerned. Some statements report significant difference in the perception of both samples. "I learn best when the teacher makes learning fun" has been favored more by the girls and a higher mean value indicates that they prefer to make learning fun more than boys and the mean values remain (3.09) and (2.92) respectively. But both the groups demonstrated highly significant difference in statement (8) which presents that "I learn best when I work alone in class." Highly significant difference is also calculated for the item that elicited samples' response regarding their liking for strict teachers. Girls exhibited extreme disliking for strict teachers and they assigned an extremely lower mean value of only (3.28) than of boys (3.35). "I like groupwork" is another statement about which both samples differ significantly. Boys responded rather positively to this valuable teaching technique as compared to the girls. Another statement where both samples are found having significant difference is the one that elicited their responses about correcting their mistakes by themselves. Both groups dislike this option and girls' responses are rather negative. Generally speaking, both groups are found of the same option as far as the majority of the items are concerned. The data generated by the Independent sample $\mathrm{T}$ Test also indicates that the sample responded to the questionnaire items after reasonable deliberation. The results have also indicated that though each human being carries one's specific trends and preferences regarding learning styles and evaluation techniques, the samples that belong to the same culture and regional background carry significant similarities.

\section{Conclusion}

Based on the results obtained from the questionnaire used, it was demonstrated that most of the students use different learning styles. EFL students learn better if the new material is taught through appropriate learning styles with efficient and valid methods. Learning style can always reinforce methods of teaching and learning. These results offer deep insights into the fact that samples' preferences have useful educational importance. The variation in the samples' responses have revealed that it seems extremely difficult to have a group of learners in a classroom who completely resemble each other in terms of their learning styles and evaluation techniques. The findings seem to suggest that teachers need to accommodate individual differences to ensure efficient teaching. The results of the questionnaire's statistical analysis reveal that it is not probable to find learners have the same kind of learning preferences in a classroom; but noticeable similarities have been witnessed. Therefore, the study has focused more to find out samples' most proffered and least preferred learning strategies and evaluation techniques instead of grading them into various kinds of learners. Teachers need to have rather clearer pictures of their learners' proffered and least preferred involving various class exercises, an assessment method and instruments. In brief, the notion of matching learning and teaching preferences can assist students act more affirmatively to educational methods, and notify faculty about operative teaching usages. Furthermore, it seems that Sudanese EFL university students' choice of learning styles can be affected by the kind of their perspective. That is, learners who had positive attitude used these strategies more regularly than those with negative attitude. In the light of these findings, the following could be recommended:

1.To utilize these learning styles effectively, lecturers should provide their students with real-life experiences and stimulation.

2. Teachers should be aware of their students' different learning styles. They sometimes need to change these learning styles according to their teaching practices. Teachers should also ensure that these learning styles satisfy their students' needs and they should consider that their students have different attitudes to learning.

3. It is highly preferable that instructors need to use different visual aids as much as possible because both groups have declared that they learn best when teaching aids such as pictures, movies and videos are used (Ahmed, 2018).

4. It is strongly suggested that group work and pair work can be practiced more in the classrooms to increase students' talking time. But it must be ensured that the students should not use Arabic while talking to each other in group/ pair work. The use of the student' native language should be confined to specific and indispensable situations.

5.It is also advised that course syllabus should be distributed at the early of the first week because both groups have exhibited strong preferences for following the textbooks closely.

6. Lecturers need to assess the textbooks and other issues they use to check if they involve different styles. Teachers should always trace updated textbooks or other teaching facilities which include language learning styles. 
7. Instructors require to revise their own teaching methods and evaluation techniques. According to LessardClouston (1997), lesson plan and presentation stimulate the undergraduates to use a diversity of learning styles and strategies.

8. It is recommendable that the teachers' aim is to make use of their best level to keep the classroom atmosphere more sociable and undisturbed so that the learners get encouraged to include themselves in different language activities. Strict and over disciplined classrooms were disliked by both the samples.

9. It is also recommended that teachers should train their students to master various test-taking strategies (Ahmed, 2018). These sessions should be practiced especially before the final examinations so that they might be able to exploit these strategies in their exams in better possible manners.

10. Teachers should enhance students' knowledge about learning styles and their usefulness. They should involve their students in a diversity of communicative tasks. Thus, the role of a teacher should be adjusted to that as a mediator who stimulates students' dynamic participation in the teaching and learning processes.

11. It is advised that class quizzes and tasks should be kept limited because both groups disapproved taking frequent quizzes and tasks. It is recommended that teachers should discuss the advantage of this technique if it is important to give them regular assignments or quizzes.

To sum up, investigations into language learning styles have thus postulated enormous significance as further and further language learning classes are being learner-centered. Appropriate and useful learning styles are highly demanded for learners.

\section{Acknowledgements}

Many thanks to Dr. Mohammed Ahmed Haj Ali El-Zuberi-an associate professor-for his valuable moments he devoted to the process of distributing and collecting the questionnaire among the students at the English Department in Faculty of Education at the University of Khartoum, Sudan.

\section{References}

Ahmed A.O.A (2018), "EFL teachers' and students' approaches in using teaching aids: A case study", Arab World English Journal (AWEJ), Special issue on CALL (4), 109-124.

Ahmed A.O.A (2018), "EFL Test preparation: Reducing EFL test-takers' stressful barriers" Journal of Applied Linguistics and Language Research (5), 113-130.

Black, P. \& William, D. (1998), "Assessment and classroom learning", Assessment in Education, 5(1), 7-74.

Brown, B.L., (2003)," Teaching style vs. learning style", Center on Education and Training for Employment, EIC Document. No. 26.

Chamot, A. U. (2008), Strategy Instruction and Good Language Learners, In C. Griffiths (Ed.), Lesson from good language learners. Cambridge: Language Teaching Library, 166-281.

Cohen, A. D. (2007). "Styles- and strategies-based instruction", retrieved March 25, 2018 from www.carla.umn.edu/strategies/SBIinfo.html.

Coombe, C. \& Hubley, N. (2004), Glossary of Important Testing Terms. In D LIoyad, P Davidson and C. Coombe (Eds.), Fundamentals of language assessment (pp. 3-16). Dubai: TESOL Arabia.

Dhaouadi, H. (2006), Alternative Assessment. In D LIoyad, P. Davidson and C Coombe (Eds.), Proceedings of the $7^{\text {th }} \& 8^{\text {th }}$ TESOL Arabia Conference, 4, (pp. 101-110). Dubai: TESOL Arabia.

Dunn, R. (1984), "Learning styles: State of the science", Theory into Practice, (23), 10-19.

Ellis, R. (1985), Understanding Second Language Acquisition. Oxford, England: Oxford University Press.

Flores, K. L., Matkin, G. S., Burbach, M. E., Quinn, C. E., \& Harding, H. (2012), "Deficient critical thinking skills among college graduates: Implications for leadership", Educational Philosophy and Theory, 44(2), 212-230

Grenfell, M. and Harris, V. (1999), Modern Languages and Learning Strategies: In theory and practice. London: Routledge.

Huxland, M. \& Land, R. (2000), "Assigning students in group projects. Can we do better than random", Innovations in Education and Training International, 37(1), 17-22.

Kang, S. (1999), "Learning styles: Implications for ESL/ EFL instruction", U. S. Department of State English Teaching Forum, 37(34).

Kikuchi, K. (2005), "Student and teacher perceptions of learning needs: A cross analysis" Shiken: JALT Testing \& Evaluation SIG Newsletter, 9(2), 8-20.

Lessard-Clouston, M. (1997), "Towards an understanding of culture in L2/FL education", The Internet TESL Journal, 3(5), 12.

Lovelace, M. K. (2005), "Meta-analysis of experimental research based on the Dunn and Dunn model", The Journal of Educational Research, 98(3), 176-183.

McGlinchey, M. T., \& Hixson, M. D. (2004), "Using curriculum-based measurement to predict performance on state assessments in reading", School Psychology Review, (33) 193-203. 
Nunan, D. (1988), The Learner Central Curriculum. Cambridge: Cambridge UP.

Ogden, W.R., (2003), "Reaching all the students: The feedback lecture", Journal of Instructional Psychology, 30 (1), 22-27.

Oxford, R.L. (1990), Language Learning Strategies: What Every Teacher should know, Boston: Heinle \&Heinle

Oxford, R. (1995), Language Learning Strategies. Boston: Heinle \&Heinle

Pintrich, P. R., \& Johnson, G. R. (1990), "Assessing and improving students' learning strategies:, New directions for teaching and learning, (42), 83-92.

Reid, J. (1995), Learning Styles Preferences in the ESL/ EFL Classrooms, Boston: Heinle \& Heinle.

Rubin, L., \& Hebert, C. (2003), "Model for active learning", College Teaching, 46(1), 25-31.

Shohamy, E. (2001), The Power of Tests: A Critical Perspective on the Uses of Language Tests, Pearson Education Limited.

Tannennbaum, E. (1996), "Practical ideas on alternative assessment for ESL students", retrieved December 8, 2018 from http://www.ericfacility.net/ericdigests/ed395500.html

Van, R.J. \& Abraham, R.G (1990), "Strategies of unsuccessful language learners", TESOL Quarterly 24 (2), $177-198$

Wenden, A. (1987), Conceptual Background and Utility. In A. Wenden \& J. Rubin (Eds.), Learning Strategies in Language Learning (pp. 3-13). London: Cambridge University Press

Wilson-Hull, S. (2008), "The impact of learning styles on high stakes testing: Perspectives from Mississippi Delta Area Teachers", Institute for Learning Styles Journal, (1), 41-5 